\title{
Mutasarrıflık Bütçelerine Göre Birinci Dünya Savaşı Yıllarında İzmit
}

\section{Özet}

\section{Safiye Kıranlar}

Vilayetlerin gelir ve giderlerini belirlenen bir program çerçevesinde kullanma anlayışı Tanzimat Fermanı'nın ilanından sonra önem kazanmış ve bu fermanla başlayan süreç vilayet bütçelerinin yasal zeminini oluşturan 26 Mart 1913 tarihli İdare-i Umumiye-i Vilayat Kanunu'yla tamamlanmıştır. Bu kanun vilayet meclislerinin, her yıl için, adî ve fevkalade bölümlerinden oluşan bir bütçe hazırlamasını yasal bir zorunluluk haline getirmiştir. Bu makalede Müstakil İzmit Mutasarrıflı̆ı̆'nca, yasal düzenlemeye uygun olarak hazırlanan Birinci Dünya Savaşı'na ait üç bütçesi (1916, 1917 ve 1918) değerlendirilecek ve bütçeler ışığında İzmit'in savaş yıllarındaki sosyo-ekonomik durumu aydınlatılmaya çalışılacaktır.

İrade-i seniyyelerinin onaylanmasından sonra yürürlüğe giren üç bütçede dikkati çeken en önemli ayrıntı mutasarrıflığın gelir (varidat) ve gider (masraf) tutarlarının yıldan yıla artmasıdır. Gelir miktarı 1916 yılında 2.865.560, 1917 yılında 3.626.275, 1918 yılında 5.361.250 kuruşken, gider miktarı 1916'da 2.564.821, 1917'de 3.348.275, 1918'de 4.896.250 kuruş olmuştur. Bu sayılar, gelir gider dengesini tutturma yolundaki çabayı da ortaya koymaktadır. Gelir kaynakları içinde vergiler önemli bir yekûn tutmakta ve aşar vergisinin payı da bir hayli yüksek gözükmektedir. Yol bedeli ve ilköğretimle ilgili vergiler de aşardan sonra gelen iki önemli vergi kalemidir. Gider tutarlarının eğitim, bayındırlık ve sağlık sektörüne ayrıldığı görülmekte maaş ödemelerininse büyük bir yekûna karşılık geldiği dikkat çekmektedir. Gelir ve gider miktarı daha az olan fevkalade bütçelerse İzmit hakkında daha öznel verileri yansıtmaktadır.

Anahtar kelimeler: İzmit Mutasarraflığı, vilayet bütçeleri, Birinci Dünya Savaşı, bayındırlık, eğitim

\section{Izmit During the First World War According to Lieutenant Governors' Budget}

\section{Abstract}

The understanding of using the income and expenses of the provinces within the framework of a determined program became important after the publication of The Imperial Edict of Reorganization, the process started with

Prof. Dr., Sakarya Üniversitesi, Fen-Edebiyat Fakültesi, Tarih Bölümü, kiranlar@sakarya.edu.tr. (Makale Gönderim Tarihi: 01.10.2017; Makale Kabul Tarihi: 01.12.2017) (ORCID ID: 0000-0001-7556-3797).

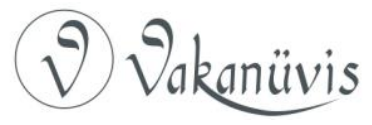


this edict was completed with the Administrative General Law of Vilayat dated 26 March 1913 which constitutes the legal basis of the provincial budget. This law has made it a legal obligation for the provincial councils to prepare a budget consisting of "vulgar" and "marvellous" sections for each year. In this article, three budgets $(1916,1917$ and 1918) of the First World War prepared by the Independent Izmit Lieutenant Governor, will be evaluated in accordance with the legal regulation and the socio-economic situation of Izmit in the war years will be tried to be illuminated in the light of the budgets.

All three budgets have entered into force after the approval of imperial decree in accordance with the legal framework. The most striking detail on these budgets is that the amount of income (expense) and expense (cost) of Lieutenant Governors have increased annually. The amount of income was 2.865 .560 in $1916,3.626 .275$ in $1917,5.361 .250$ in 1918; the expenditure amount was 2.564.821 in 1916, 3.348.275 in 1917 and 4.896.250 in 1918 . These figures also illustrate the effort to maintain an income and expenditure balance. Taxes hold a considerable share in income sources, and the share of tith seems quite high. The road costs and the Primary Education tax are two tax items that come afterwards tith. Expenditure payments are divided into education, public works and the health sector, but salary payments correspond to a large sum. The marvellous budget, which has a lower amount of income and expenditure, reflects more subjective data about Izmit.

Keywords: Lieutenant Governors of Izmit, Provincial Budgets, First World War, Public Works, Education.

\section{Giriş}

Tanzimat'ın ilanından sonra vilayetlerin mali gerçekleşmelerinin her ayın sonunda merkeze bildirilmesi kararı alınmıştı. Vilayetlerden gelecek veriler doğrultusunda bütçe oluşturulacak ve mali merkezileşme adına önemli bir adım atılmış olacaktı ${ }^{1}$. Taşranın mali anlamdaki kontrolü de demek olan bu hedefin uygulanması adına vilayetlerin bütçelerini hazırlamaları gerekiyordu ve bu yönde ilk adımlar da 1864 tarihli Vilayet Nizamnamesi'yle atılmış; birkaç vilayette uygulanan bu nizamname 1867 yılından itibaren ülke geneli için geçerli olmuştu. 1871 Vilayet Nizamnamesi kapsamında da vilayet

\footnotetext{
${ }^{1}$ Yakup Akkuş, Osmanlı Taşra Maliyesinde Reform: Merkez-Taşra Arasındaki Idarî-Malî ilişkiler ve Vilayet Bütçeleri (1864-1913), İstanbul Üniversitesi Sosyal Bilimler Enstitüsü Yayınlanmamış Doktora Tezi, İstanbul 2011, s. 201.
}

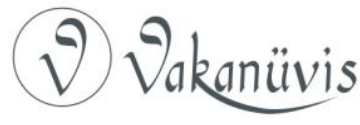


yönetimlerinden, vilayetin gelir ve giderlerinin kalem kalem gösterildiği bütçeyi o günkü deyimle varidat ve masarifat ya da muvazene defterlerini hazırlamaları istenmişti. Hazırlanan bütçe tahsisat ve tahakkuk değerlerini de içerecekti. Geçmiş yıldan kalan bakaya miktarı ise cari yıl değerlerinden ayrı biçimde gösterilecekti. Fakat bütün teknik çalışmalara rağmen vilayetlerin çoğu kez bütçelerini merkeze göndermedikleri ve hatta hiç hazırlamadıklarına tanıklık edildi ${ }^{2}$.

Devlet II. Meşrutiyet'in ilanıyla birlikte vilayetlerin bütçe hazırlama görevi konusunda daha da ısrarcı oldu ve işlerini kolaylaştırmak adına hazırlayacakları bütçe için ön adım olarak değerlendirilebilecek bir tarifname yayınladı 1909 tarihli bu tarifnamede şehriye istatistik cetvelleri adıyla anılan gelir gider durumunu gösteren cetvellerin nasıl hazırlanacağı konusuna açıklık getirildi. Merkezi idarenin bütçe konusundaki düzenlemeleri devam etti ve 1910 yılından itibaren vilayet bütçeleriyle genel bütçe arasında şekil bakımından tam bir uyum sağlanmaya çalışıldı. Bu tarifname, 1913 kanunuyla vilayetlerin hazırlamakla yükümlü oldukları bütçelerin taslak modelini oluşturdu. Belirtilen kanun 26 Mart 1913 tarihli İdare-i Umumiye Vilayât Kanun-ı Muvakkati'ydi ve kanunda bütçenin nasıl yapılacağı yönündeki açıklamalar, yol göstermeler 1909 tarifnamesinde yer alan bilgilerle neredeyse aynıydı ${ }^{3}$.

Yürürlüğe giren kanun-ı muvakkata göre vilayetler adî ve fevkalade bütçe hazırlayacaklardı. Adî bütçenin gelir kalemleri dolaylı ve dolaysız olarak alınacak vergiler; ruhsatname harçları, emval ve emlak gelirleri, kira bedelleri, genel bütçeden yapılan yardımlar, belirli hizmetler karşılığı alınacak bedeller, vilayetçe kurulan müesseselerden toplanacak gelirler, hibe ve vesayet yoluyla yapılan yardımlar şeklinde özetlenebilecek toplam 13 kalemden oluşuyordu. Gider kalemleriyse vilayet genel meclisiyle ilgili ödemelerle yol ve köprüler, eğitim, ziraat, baytarlık ve sanayi işleri, sağlık ve sosyal yardım konuları, muhtelif giderler ve borç ödemelerinden oluşmaktaydı. Fevkalade bütçe gelir kalemleri beş başlık altında toplanırken, fevkalade bütçe kapsamında

\footnotetext{
${ }^{2}$ Akkuş, a.g.t, s. 44, 202-203.

${ }^{3}$ Akkuş, a.g.t, s. 210.
}

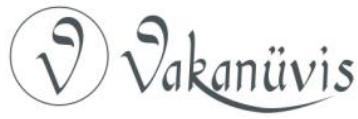


inşaat ve yeni yapılacak tesisler için gider kalemleri oluşturulmuştu ve özellikle geçici giderler için de ödenek ayrımıştı ${ }^{4}$.

Bütçenin yapılışı ve uygulanışına yönelik ince ayrıntılar da Muhasebe-i Hususiyyelerde Tutulacak Kuyûd ve Defâtir-i Hesabiyye Hakkındaki Talimatnâmenin Vilayet Bütçelerinin Suret-i Tertib ve Tanzimine Dair Olan Mevâddını Muaddil Talimatnâmedir başlıklı talimatnamede yer almaktaydı. İşte hem 1913 tarihli kanun-ı muvakkat ve hem de belirtilen tarifname doğrultusunda Müstakil i̇zmit Mutasarrıfığı'nın hazırlamış olduğu ve günümüze ulaşan bütçe kitapçıkları kapsamında Birinci Dünya Savaşı'nın İzmit'teki yansımaları bu makalenin konusudur. 1916 (1332), 1917 (1333) ve 1918 (1334) yıllarına ait mutasarrıflık bütçeleri ve 1914 ve 1915 yıllarına ait mukayese cetvelinde yer alan bilgiler doğrultusunda yapılacak değerlendirmeler, adî ve fevkalade bütçelerin gelir ve gider kısımlarının irdelenmesi ve bu bütçelere yapılan nakillerin gerekçeleriyle anlatılmasıyla devam edilecektir. Bütçe kitapçıkları dışında, bütçe içinde yapılan nakiller, mutasarrıfık yönetimi tarafından belirli konularda hazırlanan beş yıllık raporların da yer aldığı diğer arşiv belgeleri de yol gösterici olacaktır. Fakat değerlendirmelerde eksikliği hissedilen Müstakil İzmit Mutasarrıflı̆ğ'na ait olan bütçelerin günümüze ulaşmayan hesab-ı kat'ileridir.

Bütçeleri incelenecek olan İzmit Mutasarrıflığı Osmanlı idari taksimatında uzun süre eyaletlere/vilayetlere bağlı sancak olarak tanımlanmıştı. 1890 yılından itibaren müstakil livalığa/sancaklığa yükseltilen İzmit kısa bir süre İstanbul Vilayeti'ne bağlı bir birim olmuştur. 1911 yılı devlet salnamesinde müstakil liva olarak gösterilen İmit'in bu durumu Birinci Dünya Savaşı yılları boyunca devam etmiştir ${ }^{5}$.

\footnotetext{
${ }^{4}$ Muhasebe-i Hususiyyelerde Tutulacak Kuyûd ve Defâtir-i Hesabiyye Hakkındaki Talimatnâmenin Vilayet Bütçelerinin Suret-i Tertib ve Tanzimine Dair Olan Mevâddını Muaddil Talimatnâmedir, Hilal Matbaası, Dersaadet, 1330, s. 9 [Muhasebe-i Hususiyyelerde Tutulacak Kuyûd ve Defâtir-i Hesabiyye ...]; Serkan Tuna, "Kal'a-yı Sultaniye Vilayet Bütçeleri (1915-1922)", Çanakkale Tarihi, c. VI, ed. Mustafa Demir, İstanbul, 2008, s. 3169-3170.

${ }^{5}$ Müstakil İzmit Mutasarrıflığı 20 Nisan 1924 tarihli Teşkilat-ı Esasiye Kanunu uyarınca Kocaeli Vilayeti'ne dönüştürülmüştür (Enis Şahin-Sinan Demirağ, “Kocaeli Vilayeti'nin
}

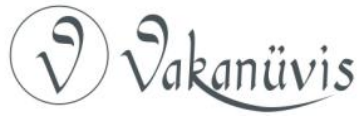


Tanzimat'tan sonra İzmit'e gönderilen Serasker Süleyman Paşa'nın etkisiyle artan imar faaliyetleri Sultan Abdülaziz döneminde de devam etti. Sultan Abdülaziz'in padişahlığının son yıllarında 1873'te açılan Haydarpaşa-izmit hattını II. Abdülhamid döneminde açılacak olan 1890 'da İzmit-Adapazarı tren hattı takip etti. Bahriye işleri anlamında 1895'te Derince Limanı́nın yapılması şehre önemli bir ayrıcalık kazandırdı ve İzmit Anadolu'dan gelen ticari malzeme ve zahirenin depolandığı şehir hüviyetini kazandı. 20. yüzyılda da İzmit'in önemli sorunlarından biri olan ve mutasarrıflık bütçeleri içinde ıslahı için para ayrılan bataklık sorunu II. Abdülhamid döneminde mutasarrıf olan Sırrı Paşa'nın ilgilendiği temel problem oldu'.

Ülkenin ticaret ve sanayi şehirlerinden biri olan İzmit sınırları içinde bulunan fabrikalar savaş yılları boyunca askeri ihtiyaçlar doğrultusunda üretim yapmışlardı․ Mutasarrıflığın Birinci Dünya Savaşı yıllarında iki mutasarrıfı ön plana çıkmaktaydı: Mazhar Müfit Bey (Kansu), ibrahim Süreyya Bey (Yiğit).

\section{İzmit Mutasarrıflığı Bütçeleri İçindeki Cetvellerin Tanıtılması}

Bütçeler yukarıda adı geçen kanun ve ilgili talimatname doğrultusunda hazırlanacak, hazırlanan bütçe vilayet meclisi tarafından onaylanacaktı. Bu noktada vilayetlerdeki ilgili şubelerin gerekli kayıtları ve özellikle gider hesaplarını doğru tutmaları önem kazanıyordu. Vilayetlerin muhasebe birimleri gider kalemlerinde eksiklik ya da fazlalık varsa bunları gerekçeli kararla birlikte ilgili şube memurları tarafından verilecek bilgi doğrultusunda yazmak ve bütçe mukayese defteri olarak hazırlamakla yükümlüydü. Bu defter bir yıl zarfında yapılan harcamaları fazlası ya da eksiğiyle göstermekteydi ${ }^{8}$. İzmit Mutasarrıflığı'nın günümüzü ulaşan 1914 ve 1915 yıllarına ait mukayese defteri de bu şekilde hazırlanmıştı.

İzmit Mutasarrıflığı'nın resmi prosedür uyarınca gelirlerini oluşturan vergi ve rüsûmlar, diğer vilayetlerde olduğu gibi, Maliye Nezareti

Teşekkül Süreci", Uluslararası Gazi Süleyman Paşa ve Kocaeli Tarihi Sempozyumu III, c. II, Kocaeli, 2017, s. 1463, 1482).

${ }^{6}$ Idris Bostan, "İzmit", DiA, c. 23, ìstanbul, 2001, s. 538.

${ }^{7}$ Adnan Sofuoğlu, Kuva-yı Milliye Döneminde Kuzeybatı Anadolu 1919-1921, Ankara, 1994, s. 20.

${ }^{8}$ Muhasebe-i Hususiyyelerde Tutulacak Kuyûd ve Defâtir-i Hesabiyye ..., s. 4.

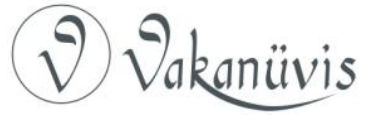


tarafından mutasarrıflık adına toplanacak, turuk ve maabir (yollar ve köprüler) bedellerinin tahakkuk işlemlerinde nüfus idarelerinin desteği alınacak ve toplanan veriler doğrultusunda muhasebe birimi hazırladığı tahakkuk defterlerini her sene başından en az on beş gün önce mal sandıklarına gönderecekti. Gelirlerin büyük bir kısmı bu şekilde toplanırken, bütçeler içinde ikinci kısım olarak görülen ve özel vergiler olarak adlandırılan kısımdaki gelirler mutasarrıflıkça belirlenecek yöntemler çerçevesinde tahsil edilecek ve her ayın sonunda kaza ve merkezdeki tahakkuk ve tahsilat verilerini içeren cetveller düzenlenecekti. Toplanan gelirlerin yeterli olmaması durumunda tahsisat-ı munzamma adıla ek bir ödenek devreye sokulabilecek ve olağanüstü durumlar için tahsisat-ı fevkalade adıyla bir ödenek konulabilecekti ${ }^{9}$.

Bütçelerin hesap devresi on iki, mahsup işlemleri ise iki aydı ve on iki aylık hesap devresi mart ayı başından şubat sonuna kadar olan devreyi kapsamaktaydı. Bir yılın bütçesinden verilecek fazla, ertesi yıl artışın olduğu fasla ilave edilecekti. İzmit Mutasarrıflığı bütçeleri içinde de sıklıkla tesadüf edilen bütçe içindeki fasıldan fasıla nakillerde mutasarrıfık meclisi ve padişahın iradesi gerekirken, aynı fası içindeki nakillerde de mutasarrıfık muhasebe müdürünün onayı ve mutasarrıflık encümeninin kararı koşulu getirilmişti ${ }^{10}$.

Bütün veriler toplandıktan sonra bütçenin oluşturulması işlemi başlıyordu. Bütçede gelir ve gider miktarını ve o yıl uygulanacak mevad-ı saireyi de içeren bir nizamname yer alacaktı. Bütçe, nizamnamesinin de yer aldığı bir kitapçık haline getirilecekti ve bu kitapçıklar 4 ana cetvelden oluşacaktı. Kitapçıkların yoğunluğunu Elif (') ve B (ب) kısmı olarak anılan yukarıda da içeriği az çok açıklanan gelir (varidat) ve gider (masarifat) cetveli oluşturmaktaydı; diğer iki cetvelden biri S (ث) diğeri de T (ت) cetveliydi.

İlgili birim tarafından hazırlanan bütçe mutasarrıflık meclisinde görüşülüp, onaylandıktan sonra iradesi çıkıyordu ${ }^{11}$. Bu noktada savaş

\footnotetext{
${ }^{9}$ Tuna, a.g.m., s. 3170-3171.

${ }^{10}$ Tuna, a.g.m., s. 3170.

${ }^{11}$ İzmit Mutasarrıflığı bütçelerinin onaylandığına dair iradeler için bkz. Başbakanlık Osmanlı Arşivi (BOA), Dahiliye Nezareti, Umur-ı Mahalliye ve Vilayat Müdüriyeti Evrakı (DH.UMVM), 26-10, ek 6: 11 Mart 1331/24 Mart 1915; Dosya Usulü İradeler Tasnifi (i.
}

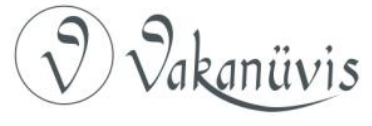


yıllarında mutasarrıflık/vilayet meclislerinin toplanıp toplanmadığı konusu önem kazanmaktadır. Birinci Dünya Savaşı yıllarına ait günümüze ulaşan İzmit Mutasarrıflığı bütçelerinde 1916 yılı bütçesiyle ilgili farklı bir ayrıntı dikkat çeker; o da aynı yılın bütçesinde yapılacak nakillerin meclis kapalı olduğu için mutasarrıflık encümeni tarafından yapıldığıdır ${ }^{12}$. Savaş nedeniyle neredeyse bütün vilayetlerin aynı durumda oldukları biliniyordu ve bu konuyla ilgili umum telgrafta vilayetlere;

vilâyât ve elviye-i mülhakanın sene-i mezkûre muvazene-i hususiyyeleri tasdik edilinceye kadar üç yüz otuz iki senesi zarfında üç yüz otuz bir sene-i muvazene-i hususiyyelerinin

cari olacağı kararı iletilmişti ${ }^{13}$. Kısacası bütçelerin onaylanması savaşın getirdiği olağanüstü durum nedeniyle gecikmiş ve ilgili yılın bütçesi onaylanıncaya kadar bir önceki yılın bütçesi üzerinden işlem yapılması uygun görülmüştü ${ }^{14}$. Bu durumun 1916 bütçesinden sonra 1917 ve 1918 yılı bütçeleri için de, İzmit Mutasarrıflığı özelinde, geçerli olduğuna tanıklık edilmiştir.

İzmit Mutasarrıflığı bütçeyi biri sadarete, diğeri Dahiliye Nezareti'ne ve bir tanesi de iradesi hazırlandıktan sonra tekrar İzmit'e gönderilecek şekilde üç nüsha halinde hazırlamak zorundaydı. 1918 yılından sonra nüsha sayısı dörde çıkarıldı ve bir nüshanın Takvim-i Vekayi komisyonuna gönderilmesi zorunlu kılındı ${ }^{15}$. Bütçe konusunda Dahiliye Nezareti aracılığılla merkezin sıkı bir kontrolü vardı ve merkez gerektiğinde, 1915 yılı bütçesi içinde yer alan fasıllardaki meblağlarla ilgili düzeltmeler konusunda İzmit Mutasarrıflığı'nın uyarılması örneğinde olduğu gibi, bizzat yerel yönetimleri uyarıyordu. Mutasarrıflık yönetimi Dahiliye Nezareti tarafından telefon tamir

DUiT), 134-32, ek 1: 11 Şubat 1331/24 Şubat 1915; i. DUiT, 131-10, ek 1: 11 Mart 1334/1918.

${ }^{12}$ BOA, I.DUiT, 134-28, ek 2: 29 Kanun-i sani 1332/11 Şubat 1917.

${ }^{13}$ BOA, I.DUIT, 128-80, ek 1: 6 Mart 1332/19 Mart 1916.

${ }^{14}$ Bu konuyla ilgili olarak bkz. BOA, I.DUiT, 128-81, ek 1: 3 Mart 1333/1917; ek 2: 15 Şubat 1333/1917.

${ }^{15}$ BOA, DH.UMVM, 37-15, ek 1: 13.7.1334/1918.

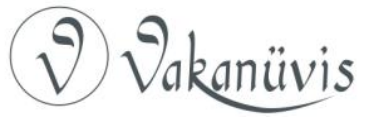


masrafı olarak ayrılan tutarın bütçeye dahil edilmesinin kanunen uygun olduğu konusunda uyarılmıştı ${ }^{16}$.

\section{Birinci Dünya Savaşı Yıllarına Ait İzmit Mutasarrıflı̆ı̆ Bütçelerinin Genel Özellikleri}

İzmit Mutasarrıflığı'nın incelenen bütçeleri ilgili yasa ve talimatnamelere uygun olarak hazırlanmış, iradeleri yayınlanarak yürürlüğe girmişti. Yukarıda da belirtildiği gibi İzmit'in 1916, 1917, 1918 yıllarına ait adî ve fevkalade bütçelerinin gelir ve gider miktarlarını belirten irade-i seniyyeleriyle birlikte ${ }^{17} 1914$ bütçesiyle 1915 bütçelesinin mukayesesinin yapıldığı mukayese cetveli mevcut olup her iki yılın bütçesinin sadece gelir ve gider fasıllarına ait tutarlarının olduğu kısım ve alt başlıkların gösterilmediği Elif ve $B$ cetvelleri günümüze ulaşmıştır ${ }^{18}$.

1916, 1917 ve 1918 yılları bütçelerinin ilk kısmını oluşturan nizamnamelerin hemen hemen aynı formülasyonda hazırlandığı, fakat 1917 bütçe nizamnamesinde küçük bir farklılık olduğu görülür. Şöyle ki; İzmit Mutasarrıflı̆ı̆'nın 1916 ve 1918 yılları bütçe nizamnameleri 9 madde, 1917 yılı bütçesi ise 8 maddeden oluşmaktadır. Nizamnamelerde gelir ve gider toplamının verildiği ilk iki maddeden sonra, $T$ cetvelinde gösterilen vergi ve rüsûmların o yıl da toplanacağı, bir önceki yıl tahakkuk etmesine rağmen ödenmeyen borcun o yılki bütçenin aynı fasıl ve maddelerine ekleneceği, mutasarrıflık meclisinin tatilde bulunduğu sırada mutasarrıflık encümeninin ayıracağı ödeneklerin S cetveli içinde açıklandığı bilgisi yer alır. Nizamnamelerde tarik bedel-i nakdisi hakkında da açıklama yapılır; 1916 ve 1918 yılı bütçelerinde mükellef başına ödenmesi gereken tutar 40 kuruş iken 1917 yılında 36 kuruş olarak belirlenmiştir. Nizamnamelerde Tedrisat-ı İbtidaiyye Kanunu'nun 15. maddesi uyarınca alınacak vergiye atıf

\footnotetext{
${ }^{16}$ BOA, DH.UMVM, 26-10, ek 3: 17 Mart 1331/30 Mart 1915.

17 BOA, Dahiliye Nezareti İdare-i Umumiye Evrakı (DH.iUM), 26-10, ek 6: 11 Mart 1331/24 Mart 1915.

${ }^{18}$ Nail İnal, İzmit Sancağı 1330 Büdcesi ve Meclis-i Umûm (1 Mart 1914-1 Mart 1915), İzmit, 2010, s. 134-135.
}

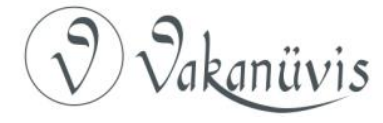


yapılırsa da mutasarrıflığın 1917 yılı bütçe nizamnamesinde bu vergiyle ilgili herhangi bir karara rastlanmaz ${ }^{19}$.

Bütçe nizamnamesinden sonra bütçedeki gelir kalemlerinin yasal dayanaklarının yer aldığı T cetveli öncelikle incelenmelidir. Bütün vilayet bütçelerinde aynı ve oldukça ayrıntılı olarak hazırlandığı görülen bu cetvel İzmit Mutasarrıflı̆ı tarafından her yıl aynen kopya edilmiştir. Mutasarrıflık bütçe gelirlerinin yasal dayanaklarının gösterildiği bu cetvelde en önemli paya sahip gelirin aşar olduğu görülür. Aşar gelirlerinin dayanağını oluşturan iki düzenlemeden biri 1909 bütçesiyle aşar gelirinin maarif hissesi üçte iki, menafi hissesinin de üçte bir olarak tayin edilmesi, diğeri de 2 Ağustos 1914 tarihli kanunla aşar üzerinden alınan menafi ve maarif hisseleri hasılatının önce genel bütçeye aktarılması ve oradan vilayet bütçesine gönderilmesidir ${ }^{20}$.

Mutasarrıflık bütçe gelirleri içinde yüklü bir bedele karşılık gelen tarik bedel-i nakdi hissesinin, T cetveline göre, 6 Mart 1915 tarihli kanuna dayandırıldığı görülecektir. Yol vergisi olarak bilinen bu vergiyi, 12 Mart 1914 tarihli geçici kanuna göre sakat ve silah altındakiler hariç $18-60$ yaş arası mükellefler ödemekle yükümlüydü ${ }^{21}$. Illgili kanuna göre vergi mükellefleri asgari 12, azami 40 kuruş vergi ödeyeceklerdi ve miktarı mutasarrıflık meclisi belirleyecekti. İzmit Mutasarrıflığı da 1916 ve 1918 yılı bütçelerinde vergi tutarını azami bedel olan 40 kuruştan tayin ederken, 1917 yılında kişi başına düşen vergi bedelini 36 kuruş olarak tespit etmişti ${ }^{22}$.

19 BOA, I.DUiT, 134-32, 1332/1916 yılı Müstakil İzmit Mutasarrıflığı Bütçe Kitapçığı [1916 yılı bütçe kitapçığı]; I.DUiT, 134-27, ek 3: Müstakil İzmit Mutasarrıflığı 1333/1917 yılı Bütçe Kitapçığı [1917 yılı bütçe kitapçığı]; i.DUiT, 131-10, ek 13: 1334/1918 yılı Müstakil İzmit Mutasarrıflığı Bütçe Kitapçığı [1918 yılı bütçe kitapçığı].

${ }^{20}$ Tuna, a.g.m., 3172-3173.

${ }^{21}$ Tuna, a.g.m., s. 3173. Vergi mükellefleri hangi vilayet nüfusuna kayıtlıysa o vilayete vergisini ödemek zorundaydı. Vergisini ödeyemeyenler ise "hükümet tarafından cebren kazaları dahilinde kasaba ve karyelerine en karib mahallere vakı tarik veya sair inşaat mahallerine sevk edilerek oralarda deynlerini ifa edinceye kadar amele sıfatıyla çalıştırılacaklardı" (Bilâ-Vasıta Tekâliften Bazılarına Vilayât Hissesi Olarak Icra Edilen Zamaim ile Zebhiye Rüsûmunun Miktarı Ve Tarik-i Mükellefiyet Nakdiyesi Hakkındaki Kavanin-i Muvakkate ile Zebhiye Resmi Hakkındaki Kanuna Tezyil Olunan Mevad-ı Muvakkata-i Kanuniyye Suretleridir, Dersaadet, tarih belirtilmemiş, s. 6-7).

${ }^{22}$ BOA, i.DUiT, 134-32: 1916 yılı bütçe kitapçığı; i.DUiT, 134-27: 1917 yılı bütçe kitapçığı; i.DUiT, 131-10: 1918 yılı bütçe kitapçı̆̆ı.

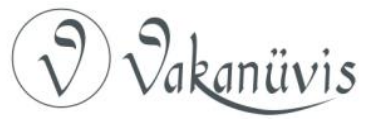


Gelir kalemleri içinde yer alan zebhiyye resmi için kanuni dayanak 11 Mart 1915 tarihli Rüsûm-ı Belediye Kanunu'yken bütçe gelirleri içinde önemli bir yekûnu tutan Maarif-i ibtidaiyye Vergisi'nin mesnedini yukarıda adı zikredilen 6 Ekim 1913 tarihli Tedrisat-ı Ibtidaiyye Kanun-ı Muvakkatı'nın 15. maddesi oluşturmaktaydı. Ilgili maddeye göre ibtidai eğitimle ilgili bina inşası, öğretmen ve müstahdem maaşları, aydınlatma, ısıtma ve onarım ve bakım işleri için gerekli olan masraflar bölge ahalisi tarafından karşılanacaktı; özetle ilköğretim merkezi hazinenin ilgi alanından çıkarılmış oluyordu. Genel olarak $\mathrm{T}$ cetvelindeki bütçe gelirlerinin yasal dayanakları izlendiğinde aşar, müsakkafat gibi önemli vergi gelirlerinin ciddi oranlarda eğitime aktarıldığı anlaşılmakta ve bu sayede eğitim için önemli bir finansman kaynağı yaratılmaktaydı ${ }^{23}$.

S cetveli de kitapçık içinde en az yekunu tutan bölümdü ve burada mutasarrıflık yönetimi tarafından yapılan bütçe içindeki nakillere atıfta bulunulmaktaydı. İzmit Mutasarrıflığı'nın incelenen üç bütçesinde $S$ cetvelinin ufak tefek değişiklikler dışında hemen hemen aynı olduğu görülür.

\section{İzmit Mutasarrıflığı Bütçelerinin Gelir Kalemleri (Elif Cetveli)}

Mutasarrıfık bütçelerinin en ayrıntılı bölümünü, varidat yani gelir kısmının gösterildiği Elif cetveli oluşturmaktaydı. Cetveldeki gelir kalemleri tekâlif-i emiriyye küsurât-ı munzamması (vergi gelirleri), küsurât-ı munzammadan maada varidat-ı hususiyye (özel gelirler) ve ianât olmak üzere üç kısımdan oluşmaktaydı. Bu kısımların her biri mutasarrıflık için toplanacak geliri ihtiva etmekteydi. Resmi prosedüre göre gelirlerdeki açık, gelir kısmındaki ianat faslında bütçe açı̆̆ı adıyla belirtilecek ve bu konuda merkezi hükümetin muvafakati alınacaktı ${ }^{24}$. Fakat mutasarrıflık bütçelerinde incelenen dönem içinde bu başlığa herhangi bir bedel konulmadığı görülecektir.

\footnotetext{
${ }^{23}$ Tuna, a.g.m., s. 3173.

${ }^{24}$ Tuna, a.g.m., s. 3174-3175.
}

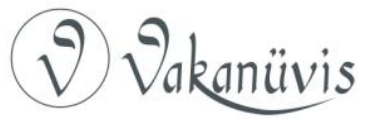


TABLO I: 1916, 1917 ve 1918 yılı bütçelerinin gelir kalemleri (kuruş olarak)

\begin{tabular}{|l|l|l|l|}
\hline Yıl & Birinci Kısım & İkinci Kısım & Toplam \\
\cline { 2 - 4 } & $\begin{array}{l}\text { Vergi gelirleri } \\
\text { (Tekâlif-i Emiriyye } \\
\text { Küsurat-ı } \\
\text { Munzamması) }\end{array}$ & $\begin{array}{l}\text { Özel gelirler } \\
\text { (Küsurât-ı } \\
\text { munzammadan } \\
\text { maada varidat-ı } \\
\text { hususiye) }\end{array}$ & \\
\hline $1914(1330)$ & - & - & 3.832 .900 \\
\hline $1916(1332)$ & 1.362 .020 & 1.503 .540 & 2.865 .560 \\
\hline $1917(1333)$ & 2.663 .390 & 962.885 & 3.626 .275 \\
\hline $1918(1334)$ & 4.153 .250 & 1.208 .000 & 5.361 .250 \\
\hline
\end{tabular}

Kaynak: BOA, I.DUiT, 134-32: 1916 yılı bütçe kitapçığı; i.DUiT, 134-27: 1917 yılı bütçe kitapçığı; I.DUiT, 131-10: 1918 yılı bütçe kitapçığı

TABLO I’e göre üç yılın ortalama vergi geliri 2.726.220 kuruştur ve yıldan yıla artış göstermektedir. İkinci kısımda yer alan özel gelirlerde 1917 yılı itibarıyla gözle görülür bir düşüş dikkati çeker ve savaşın son yılında ise seyir ters istikamete döner. 1917 yılı ülkede savaşın bütün sıkıntılarının derin bir şekilde hissedildiği yıldır. Zaten devlet bu tarihten itibaren bütçe adına kesintiler yapmaya başlayacak ve kontrollü bütçe mantığıyla hareket eden vilayetlerdeki bütçe hazırlayıcıları bu hususa önem vereceklerdir. Fakat bunların tahmini gelirler olduğu ve hesab-ı kat'ilerinin olmadığı tekrar tekrar hatırlatılmalıdır. Gelir fasıllarının daha ayrıntılı olarak açıklanması adına TABLO II ve TABLO III'teki veriler daha doğru yorumlar yapmak adına önemlidir:

TABLO II: Müstakil İzmit Musarrrıflığı Adî Bütçelerinin Birinci Kısmında Yer Alan Gelir Kalemleri (kuruş olarak)

\begin{tabular}{|l|l|l|l|}
\hline Vergi gelirleri & 1916 & 1917 & 1918 \\
\hline Aşar menafi ve maarif hissesi & 802.050 & 2.426 .590 & 3.930 .000 \\
\hline $\begin{array}{l}\text { Musakkafat vergisi, maarif ve } \\
\text { taraf-ı vilayet hissesi }\end{array}$ & 80.900 & 99.750 & 99.250 \\
\hline $\begin{array}{l}\text { Temettü vergisi ve tarik-i vilayet } \\
\text { hissesi }\end{array}$ & 13.490 & 41.000 & 24.000 \\
\hline $\begin{array}{l}\text { Ağnam, deve, manda, domuz } \\
\text { rüsûmu hisseleri }\end{array}$ & 60.700 & 59.750 & 60.000 \\
\hline Ferağ ve intikal harçları hisseleri & 23.500 & 28.750 & 30.000 \\
\hline Bedel-i nakdi-i askeriyye hissesi & 280.200 & 0 & 0 \\
\hline
\end{tabular}




\begin{tabular}{|l|l|l|l|}
\hline Tarik-i vilayet hissesi & 101.180 & 7.550 & 10.000 \\
\hline Toplam & 1.362 .020 & 2.663 .390 & 4.153 .250 \\
\hline
\end{tabular}

Kaynak: BOA, I.DUiT, 134-32: 1916 yılı bütçe kitapçığı; i.DUiT, 134-27: 1917 yılı bütçe kitapçığı; İ.DUiT, 131-10: 1918 yılı bütçe kitapçığı

Tabloda görüldüğü üzere mutasarrıflığın bütçe gelirleri içinde aşar ve maarif hissesi ortalama olarak 2.386 .213 kuruş ve $\% 87,5$ payla en büyük kalemi oluşturmakta ve düşüş eğilimi görülen diğer fasıllara karşın, bu fasılda her yıl ve özellikle 1917 yılında yüksek bir ivmeyle artışa tanıklık edilmektedir ${ }^{25}$. Bu da nüfusunun büyük çoğunluğunun köyde yaşadığı mutasarrıflık adına normal bir durum olarak değerlendirilmelidir ve mutasarrıflığın 1919 ve 1920 yıllarına ait bütçelerinde de bu durum devam edecektir ${ }^{26}$. Her ne kadar köylüyle ilgili olan ağnam, deve, manda, domuz rüsumu hissesi diğer kalemlere göre çok düşük olsa da tablodaki rakamlar İzmit köylüsünün bütçe gelirleri üzerindeki derin etkisini ortaya dökmektedir.

Aşar ve maarif hissesindeki artışın tam tersi istikamette ilerleyen, Elif cetveli içinde hem birinci hem de ikinci kısımda yer alan tarik bedeli tutarı 1917 yılında birden bire artıp, sonradan aynı hızla düşmüştür. Birinci kısımda yer alan tarik-i vilayet hissesinin temettü vergisiyle birlikte gösterilmesi dikkatten kaçırılmamalıdır. Bütçe içinde temettü vergisiyle ilgili herhangi bir açıklamanın olmaması değerlendirme konusunda sıkıntı yaratmaktadır. Görülen artışta temettü vergisi gelirinin katkısının çok daha fazla olduğu iddia edilse yanlış olmayacaktır. Bu arada TABLO III'deki vilayete ait temettü hissesinin 1917 yılında 0 kuruş olarak gösterildiği gerçeği de hesaba katılmalıdır. Bedel-i nakdi-i askeri hissesi 1916 yılı bütçesi içinde varken savaşın son iki yılı bütçesinde yer almaz.

TABLO III: Müstakil İzmit Mutasarrıflığı Adî Bütçelerinin İkinci Kısmında Yer Alan Gelir Kalemleri (kuruş olarak)

\footnotetext{
${ }^{25} \mathrm{Bu}$ arada İzmit Mutasarrıflığı dahilinde tesis olunacak bağların beş sene müddetle aşar vergisinden muaf tutulduğu belirtilmelidir (Meclis-i Mebusan Zabıt Ceridesi (MMZC), i: 12, 1 Kanunevvel 1332/1916, s. 130).

${ }^{26}$ Bkz. BOA, DUiT, 131-11: 1919 yılı bütçe kitapçığı; DUiT, 131-24: 1920 yılı bütçe kitapçı̆̆ı.
}

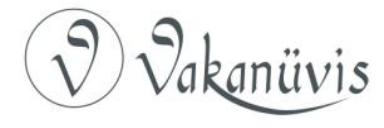




\begin{tabular}{|l|l|l|l|}
\hline Özel Gelirler & 1916 & 1917 & 1918 \\
\hline Tarik bedel-i nakdisi & 815.900 & 634.875 & 354.000 \\
\hline Rüsûmat & 69.200 & 65.900 & 79.000 \\
\hline Emlak ve Akar Geliri & 53.080 & 37.200 & 73.300 \\
\hline Maarif-i ibtidaiyye geliri & 500.000 & 223.100 & 700.000 \\
\hline Diğer gelirler & 2.600 & 1.810 & 1.700 \\
\hline $\begin{array}{l}\text { Vilayete ait hisse-i temettü } \\
\text { (Ziraat Bankası hisse-i temettüsü) }\end{array}$ & 62.760 & 0 & 0 \\
\hline Toplam & 1.503 .540 & 962.885 & 1.208 .000 \\
\hline
\end{tabular}

Kaynak: BOA, I.DUiT, 134-32: 1916 yılı bütçe kitapçı̆̆ı; I.DUiT, 134-27: 1917 yılı bütçe kitapçığı; I.DUiT, 131-10: 1918 yılı bütçe kitapçığı

TABLO III'e göre yol vergisi (tarik bedel-i nakdisi) olarak adlandırılan tahmini tutarın diğer kalemlere oranla üç yıl için ortalama 601.592 gelirle \% 49'luk bir pay tuttuğu görülür. Bu noktada verginin ne kadarının toplandığı konusu önem kazanır. Çünkü hesaplanan değer, tahmini gelir bedeli üzerinden yapılmakta ve verginin ne kadarının tahakkuk ettiği bilinmemektedir. Üstelik yol vergisini nakit olarak değil çalışarak ödeyenlerin sayısının ne olduğu konusu da açmazın diğer bir tarafıdır. En büyük düşüş yine bu kalemde görülmekte ve özellikle savaşın son yılı bu bağlamda önem kazanmaktadır. Yol vergisinin tarhıyla elde edilecek olan tarik-i vilayet hissesindeki 1917 yılına ait düşüşün nedenlerinden biri kişi başına ödenecek bedelin önceki ve sonraki yıldan daha az bir bedelle alınmasındandır. Belirtilen yılda 36 kuruş alınacakken 1916 ve 1918 yıllarında 40 kuruşta karar kılınmıştı. Ayrıca maarif-i ibtidaiyye tahmini değerinin 1917 yılı içinde ani bir inişle, 1918 yılında hızı bir artışla 700.000 kuruş bedeline ulaşması dikkat çeker.

Mutasarrıflık gelirleri içinde ele alınması gereken bir diğer unsur fevkalade bütçelerinin gelir kalemleridir. TABLO IV'te üç yılın fevkalade bütçelerinin gelir tutarları gösterilmiştir.

TABLO IV: Müstakil İzmit Mutasarrıflığı Fevkalade Bütçesi Gelir Kalemleri (kuruş olarak)

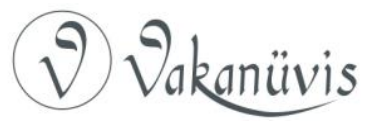




\begin{tabular}{|l|l|l|l|}
\hline Gelirler & 1916 & 1917 & $1918^{27}$ \\
\hline $\begin{array}{l}\text { Adi bütçenin fazla } \\
\text { varidatı }\end{array}$ & 300.739 & 278.000 & 455.000 \\
\hline & 300.739 & 278.000 & 455.000 \\
\hline
\end{tabular}

Kaynak: BOA, I.DUiT, 134-32: 1916 yılı Müstakil İzmit Mutasarrıflığı Fevkalade Bütçe Kitapçı̆̆ı; I.DUiT, 134-27: 1917 yılı Müstakil İzmit Mutasarrıfı̆ğı Fevkalade Bütçe Kitapçığı; I.DUiT, 131-10: 1918 yılı Müstakil İzmit Mutasarrıflığı Fevkalade Bütçe Kitapçığı

Tablodan da anlaşılacağı üzere İzmit Mutasarrıflığı'nın fevkalade bütçelerinin tek geliri adî bütçeden aktarılan paylardır. Bu paylarla ilgili herhangi bir bilgi ya da açıklama yoktur; adî bütçenin hangi faslının fazla verdiği konusu net değildir.

\section{Mutasarrıflık Bütçelerinin Gider Kalemleri Doğrultusunda Birinci Dünya Savaşı Yılları İzmit'i Hakkında Değerlendirmeler}

Bütçelerin gelir tutarları savaş boyunca artmış olmakla birlikte, giderlerdeki artışı yakalayamamış yaşanan olağanüstühalse var olanı sürdürme anlayışını benimsemeyi zorunlu kılmıştır. Mutasarrıflık yönetimi günden güne kötüleşen ekonomik seyri durağan tutmak için çalışmış, harcamalar en aza indirilirken, birden bire ortaya çıkan masraflar için bütçe içinde nakiller yapılmıştır. İzmit Mutasarrıflığı hükümet konağında çıkan yangın sonrasında bütçe içinde yapılan nakil bu konuya verilecek yüzlerce örnekten bir tanesidir. Belirtilen yangında muhasebe-i hususiye ve encümen-i ihsaiyat dairelerinin içindeki eşyalar yanmış ve 1918 yılı bütçesine encümenin isteği doğrultusunda 30.000 kuruş tahsisat ilave edilmişti ${ }^{28}$. Nakil örneklerinde olduğu gibi bütçe içinde yeni fasıl açma durumu da yaşanmış, her iki uygulamada ilgili kanun ve talimatnamede belirtilen yasal kriterlere uyulmuştu. Örneğin mutasarrıflık bütçesinde açılan telefon zabtı ve tesisat ve tamiratı başlıklı fasıl Dâhiliye Nezareti'yle uzun yazışmalara neden olmuştu. Mutasarrıflık yönetimi telefon hatlarının inşası konusunda bir hayli duyarlıydı. İzmit telefon hatları için gerekli meblağın büyük bir

\footnotetext{
${ }^{27}$ BOA, I.DUiT, 131-10: 1918 yılı bütçe kitapçığı.

${ }^{28}$ BOA, I.DUiT, 131-10, ek 10: 12 Haziran 1918. Yangın 28 Ocak 1918'de çıkmış ve yangında 13.678 adet evrak yanmıştır (Osmanlı Belgelerinde Kocaeli, İstanbul, 2017, s. 370) [Osmanlı Belgelerinde Kocaeli adlı esere ulaşmamı sağlayan Resul Narin'e teşekkür ederim].
}

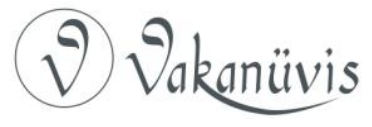


kısmı iane-i ahali ile toplamıştı ve üstelik inşaatla iş bitmiyor, telefon hattının bakımı ciddi bir külfeti beraberinde getiriyordu. Bu nedenle mutasarrıfık yönetimi 1915 yılı bütçesi için 5.000 kuruş ayrılmasını isteyip gereken parayı yine iane-i ahaliyle toplamayı talep edince Dâhiliye Nezareti onay vermedi. Sonunda orta yol bulundu ve belirtilen yılın bütçesinin herhangi bir faslından nakil yapılamadığı için iane-i ahali ile tesis edilmiş olan telefon masraf-ı tamiriyyesi adıyla 1915 yılı bütçesinde fasıl açıldı ${ }^{29}$.

İzmit Mutasarrıflığı bütçelerinin gider kalemleriyle ilgili değerlendirmelerde, 1916 yılında geçerli olmak üzere, 5 yıllık plan şeklinde hazırlanan raporların göz ardı edilmemesi gerekir. Adı geçen planlarda, İzmit Mutasarrıflığı bütçeleri içinde de yer alan turuk ve maabir, umur-ı maarif ve umur-ı ziraiyye ve baytariye, maarif, umur-ı hayriye ve sıhhiye alanlarında beş yıl içinde yapılması hedeflenen inşa işleriyle ilgili hedefler yer almaktadır ${ }^{30}$. Bir diğer dikkate alınması gereken her yılın fevkalade bütçelerinin gider kısımlarıdır. Raporlar ve fevkalade bütçelerle ilgili karşılaştırmayı yapabilmek adına aşağıdaki TABLO V'te yer alan İzmit Mutasarrıflığı bütçelerinin gider kalemleriyle, TABLO VI'da gösterilen fevkalade bütçelerinin gider kalemleri öncelikle ele alınmalıdır:

TABLO V: İzmit Mutasarrıflığı Bütçelerinin Gider Kalemleri (Kuruş olarak)

\begin{tabular}{|l|l|l|l|l|l|}
\hline Masraf & 1914 & 1915 & 1916 & 1917 & 1918 \\
\hline $\begin{array}{l}\text { Meclis-i } \\
\text { umumi ve } \\
\text { muhasebe- } \\
\text { i hususiye-i } \\
\text { vilayet }\end{array}$ & 183.715 & 212.250 & 195.400 & 209.600 & 237.300 \\
\hline $\begin{array}{l}\text { Turuk ve } \\
\text { Maabir }\end{array}$ & 1.972 .453 & 288.653 & 240.226 & 215.400 & 192.700 \\
\hline $\begin{array}{l}\text { Umur-I } \\
\text { maarif }\end{array}$ & $603.252,20$ & $1.220 .309,20$ & 1.533 .395 & 1.529 .190 & 2.117 .020 \\
\hline
\end{tabular}

${ }^{29}$ BOA, DH.UMVM, 26-10, ek 9: 28 Eylül 1331/11 Ekim 1915; ek 8: 10 Teşrin-i evvel 1331/23 Ekim 1915; ek 10: 3 Eylül 1331/16 Eylül 1915; ek 11: 25 Teşrin-i evvel 1331/28 Ekim 1915.

${ }^{30}$ BOA, DH.UMVM, 85/28. Raporlarda ele alınan alanların turuk ve maabir, umur-ı ziraiye, baytariyye ve sanaiyye, maarif inşaatı, ziraat tesisatı konuları olduğu ve 19161920 yılları da dahil olmak üzere beş yılı kapsadığı tekrar hatırlatılmalıdır.

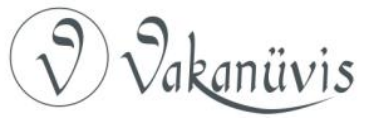




\begin{tabular}{|l|l|l|l|l|l|}
\hline $\begin{array}{l}\text { Umur-ı } \\
\text { ziraiyye ve } \\
\text { baytariyye } \\
\text { ve } \\
\text { sanaiyye }\end{array}$ & 60.100 & 62.800 & 97.700 & 67.100 & 270.680 \\
\hline $\begin{array}{l}\text { Umur-ı } \\
\text { Hayriye ve } \\
\text { sihhıye }\end{array}$ & 73.100 & 202.283 & 182.800 & 133.000 & 198.600 \\
\hline $\begin{array}{l}\text { Masarıf-ı } \\
\text { muhtelife }\end{array}$ & 568679,20 & 400278 & 315300 & 1193985 & 1879950 \\
\hline Toplam & 3461300 & 2386573,20 & 2564821 & 3348275 & 4896250 \\
\hline
\end{tabular}

Kaynak: BOA, DH.UMVM, 26-10, ek 4-5: 9 Şubat 1330/22 Şubat 1915 tarihli Müstakil İzmit Mutasarrıflığı 1331 senesi muvazene-i hususiyesine merbut mukayese cetveli; I.DUiT, 134-32: 1916 yılı bütçe kitapçı̆̆ı; i.DUiT, 134-27: 1917 yılı bütçe kitapçığı; İ.DUiT, 131-10: 1918 yılı bütçe kitapçığı

TABLO V'te 5 yıl için gösterilen toplam gider tutarı 16.657.129 kuruş olup ortalama değer 3.332.443 kuruştur ve değerlendirmeler bu tutar baz alınarak yapılacaktır. Tabloda görülen maaş ödemelerinin mutasarrıfık meclisi personeli, mutasarrıflık bünyesindeki çalışan memurlar ve ilköğretim seviyesindeki okulların başta öğretmen olmak üzere çalışanlarına yapıldığı belirtilmelidir ${ }^{31}$. Maaş ödemelerinde yıllar içinde sürekli bir artış ya da sürekli bir düşüş görülmez ki bu durum hükümetin memur maaşlarıyla ilgili aldığı kararlarla ilintilidir. Örneğin 19 Mart 1917 tarihli bir karar doğrultusunda maaşlarını vilayet bütçelerinden alan memurlara aldıkları ücret oranına göre tahsisat-ı fevkalade ayrılacak, bu doğrultuda vilayet idaresince belirli oranlarda zam yapılacak ve zam 1 Mart 1918'den itibaren geçerli olacaktı. ilgili kararname uyarınca 1.000 kuruşa kadar maaşı olanların maaşlarının yüzde \%50'si, 1.000 kuruştan 3.000 kuruşa kadar olanların toplam maaşlarının \%30'u ve 3.000 kuruştan daha çok maaş alanların maaşları toplamının \%20'sini aşmamak üzere aylık zam yapılacaktı ${ }^{32}$. Bütçelerdeki maaş ödemeleri fasıllarına bakılarak memurlara düzenli

\footnotetext{
${ }^{31}$ Vilayet bütçelerinden maaş alan personelle ilgili yapılan düzenlemeler için bkz. BOA, DH.UMVM, 8-11.

32 BOA, DH.UMVM, 45-3, ek 13: 11.5.1334/1918. 1917 yllında verilmeye başlayan zam 1919 yılından itibaren pahalıık zammı olarak adlandırılmış ve 16 Mart 1919 tarihli kararname uyarınca pahalılık zammı için mutasarrıfıı bütçesine gerekli miktarda ödenek ayrılmıştı. Bu konuda bkz. BOA, i.DUiT, 131-12.
}

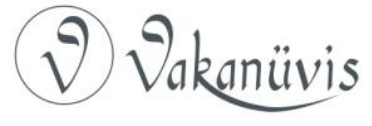


olarak ücret ödendiği düşünülmemelidir. Memurlar savaş şartlarından en çok etkilenen ücretli kesimdi ve neredeyse hepsi için geçerli olmak şartıyla aylıklarını zamanında almaları büyük bir lükstü. Üstelik resmi kayıtlara dayanan bir değerlendirmeye göre belirli kalemlerde istihdam edilen memur yoktu. Aynı değerlendirmede Adapazarı kazasının;

yazı işleri hacmi orta büyüklükteki bir liva düzeyinde olduğu halde, kadrosunda diğer kazalarda olduğu gibi sadece bir tahrirat memuru bulunuyordu. $O$ da seferberliğin ilanından beri asker olması, maaş ve ödeneğinin kendisine ödenmesi dolayısıyla yazı işleri öteki beriki tarafından yürütülmekteydi ${ }^{33}$.

Mutasarrıflık merkezindeki tahrirat kalemi memurları seferberlik emriyle askere alındıkları için oradan Adapazarı'na nakil yapılması söz konusu değildi. Buna rağmen mutasarrıflık bünyesinde 1916 yılında ihdas edilen istatistik kalemine ve bu kalemin memurları için ayrılan paraya anlam vermek mümkün değildir ${ }^{34}$.

Tablodaki masarıf-ı muhtelife olarak adlandırılan muhtelif masrafların oranlarının yüksek olması savaş şartlarına bağlanmalıdır. Bütçelerdeki gider fasılları içinde \%26,16 gibi bir orana sahip olan bu faslın içeriğinde herhangi bir alt başlığın olmaması mutasarrıflık yönetimine harcamalarında hareket serbestisi sağlamaktaydı.

Vilayet yönetimlerinin her yıl hazırlamakta oldukları fevkalade bütçeler; gelir faslında bahsedildiği gibi, adî bütçe fazlalarının aktarıldığı, adî bütçeyle mukayese edilemeyecek oranda muhtemel gelir ve gider tutarlarının bulunduğu bütçelerdi. Onların diğer bir özelliği de merkezi hazineden yapılan yardımların bu bütçeye aktarılmasıydı; fakat incelenen bütçelerde İzmit Mutasarrıflı̆ı̆'na merkezi hazineden aktarılan herhangi bir paraya tesadüf edilmemiştir.

TABLO VI: İzmit Mutasarrıflığı Fevkalade Bütçesi Gider Kalemleri (kuruş olarak)

\begin{tabular}{|l|l|l|l|}
\hline Giderler & 1916 & 1917 & 1918 \\
\hline Umur-ı maarif & 210.739 & 178.000 & 150.000 \\
\hline Umur-I ziraiyye ve & 80.000 & 100.000 & 285.000 \\
\hline
\end{tabular}

${ }^{33}$ Sabahattin Özel, Milli Mücadelede İmit-Adapazarı ve Atatürk, 2. baskı, İstanbul, 2009, s. 3.

${ }^{34}$ BOA, i.DUiт, 134-33, ek 1: 5 Mayıs 1332/18 Mayıs 1916.

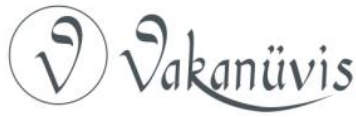




\begin{tabular}{|l|l|l|l|}
\hline baytariyye ve sanaiyye & & & \\
\hline Umur-ı Hayriye ve sıhhıye & 10.000 & - & \\
\hline Toplam & 300.739 & 278.000 & $475.000^{35}$ \\
\hline
\end{tabular}

Kaynak: BOA, I.DUiT, 134-32: 1916 yılı Müstakil İzmit Mutasarrıflığı Fevkalade Bütçe Kitapçı̆̆ı; I.DUiT, 134-27: 1917 yılı Müstakil İzmit Mutasarrıfı̆̆ı Fevkalade Bütçe Kitapçığı; I.DUiT, 131-10: 1918 yılı Müstakil İzmit Mutasarrıflığı Fevkalade Bütçe Kitapçığı

TABLO VI'da görüldüğü gibi İzmit Mutasarrıflığı fevkalade bütçe giderlerini eğitim, ziraat, hayvancılık ve sağlık ve sosyal yardım alanlarındaki harcamalara tahsis etmişti. 1916 yılı mutasarrıflık bütçesinde maarif-i ibtidaiyye masrafı 210,739 kuruş gibi bir rakamla bütçenin neredeyse 2/3'den fazlasına denk gelmekteydi ${ }^{36} .1917$ yılı fevkalade bütçesinde de aynı oran yakalanmıştı; ama 1918'de oran düşmüştü ${ }^{37}$. 1916 yılına ait bütçelerde İzmit merkez ve Geyve'deki bataklıkların kurutulması için ayrılan ödenek miktarı ikinci sırada geliyordu. 1917 yılı gibi, 1918 yılının fevkalade bütçesinin gider faslının neredeyse tamamı Geyve bataklığının kurutulması, İzmit mezbahası ve İzmit hastanesi için ayrılmıştı. Özetle gelir ve gider miktarı âdî bütçelere göre oldukça az olan üç fevkalade bütçede İzmit hakkında daha öznel verilerle karşılaşılmaktadır.

Bütçeler ve 5 Yıllık Faaliyet Raporu Doğrultusunda Birinci Dünya Savaşı Yıllarında İzmit'te Bayındırlık Faaliyetleri ve Eğitim

Adî ve fevkalade bütçeler içinde yer alan maarif, ziraat, baytariyye ve sanaiyye, umur-ı hayriye ve sıhhiye konuları, bayındırlık alanı içinde değerlendirilecek olup, değerlendirmelere İmit Mutasarrıflığı'nın hazırladığı ve yukarıda adı geçen 5 yıllık planı içeren raporu da katkı sağlayacaktır. Raporun turuk ve maabirle ilgili bölümünde, mutasarrıfık sınırları içinde yapılması planlanan yol güzergâhlarıyla, inşa edilecek yolun uzunluğunun tahmini değerleri yazılmıştı ki, bu

\footnotetext{
${ }^{35}$ [Belgenin aslında rakam bu şekilde gösterilmiştir. Toplamanın yanlış yapıılığı gözden kaçırılmamalıdır]

${ }^{36}$ BOA, İ. DUIT, 134-32: 1916 yılı bütçe kitapçığı.

37 BOA, i. DUiT, 134-32: 1916 yılı bütçe kitapçı̆̆ı; í. DUiT, 131-10: 1918 yılı bütçe kitapçı̆̆ı
}

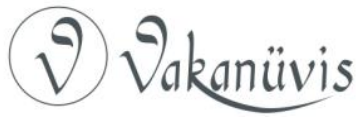


güzergâhlar İzmit-Kandıra, Adapazarı-Kandıra, Arifiye-Adliye, Karamürsel-Iznik ve Kandıra-Kefken hattıydı. Bu hatların bir kısmında inşaat savaş öncesinde başlamışsa da ilgili yılda inşaat gideri için mutasarrıflık bütçesinden ne oranda pay ayrıldığı belirtilmemişti ${ }^{38}$. Raporda geçen tahmini rakamların büyüklüğü gerekli bedelin merkezi hazine tarafından karşılanacağını göstermektedir ${ }^{39}$ ve zaten TABLO V'deki turuk ve maabirle ilgili giderde görülen, yıldan yıla seyreden düşüş bu durumun göstergesi olmalıdır.

Savaş başlamadan önce İzmit Mutasarrıflığı sınırları dâhilinde 400 km'lik yol yapımı planlanmış, inşaata başlanmış ve hatta bir şirketle anlaşma yolunda adım atılmışı. Konuyla ilgili müzakereler sürerken seferberlik ilan edilmiş ve seferberlikle birlikte müteahhitlerin maliyetin arttığı gerekçesini ortaya sürerek iş bırakmaları nedeniyle bu alanda amele taburları çalıştırılmaya başlanmıştı ${ }^{40}$. Her ne kadar mutasarrıflığın ilgili kayıtlarında amele taburları aracılığıyla bu işin görüldüğü belirtilse de bütçe içinde yer alan tahmini giderler tam tersini söylemektedir. Bütçelerdeki keşfiyat ve tamirat faslına ayrılan ödenek 1914 yılı için 1.806 .800 kuruş iken bir yıl sonra 95.000'e düşmüştür. Üstelik 1914 yılında toplam masraf tutarının, bu kısım için olmak şartıyla 1.972 .453 iken bir yıl sonra 288.653 gibi çok düşük bir rakama indiği görülecektir ${ }^{41}$. Dolayısıyla mutasarrıflık yönetimi yol ve köprü yapımı işlerini tamamen geri plana itmiş; ancak bütçenin fazla verdiği durumlarda ilgili fasıllara nakiller yapmıştır. Örneğin 1917 yılı bütçesi içindeki köprülerin tamiri için ayrılan ödeneğin yetersiz olması nedeniyle tahsisat-ı munzamma istenmiş ve mutasarrıflığın bu talebi uygun görülmüştü ${ }^{42}$. Bu arada tahsisat-ı fevkalade de bir yöntem

\footnotetext{
${ }^{38}$ BOA. DH.UMVM; 85-28, ek 1: tarih belirtilmemiş.

391917 yılı yol yapımı için ayrılan bedel 1.095 .000 kuruş olarak gösterilmişti. Bu bedelin 130.000 kuruşunun İzmit ve Geyve bataklıklarının kurutulması için ayrıldığını belirtmek gerekir (BOA. DH.UMVM; 85-28, ek 1: tarih belirtilmemiş)

${ }^{40}$ inal, a.g.e., s. 16-17.

${ }^{41}$ BOA, DH.UMVM, 26-10, ek 4-5: 9 Şubat 1330/22 Şubat 1915 tarihli Müstakil İzmit Mutasarrıflığı 1331 senesi muvazene-i hususiyesine merbut mukayese cetveli

42 BOA, I.DUiT, 131-10, ek 8: 18 Ağustos 1333/1917. Vilayetlerin gelirlerinin azlığı ve tahsil edilmesi sırasında yaşanan gecikmelerle ilgili olarak 6 Nisan 1913 tarihinde bir irade yayınlanmıştı. İradeyle geçici vilayet kanunun 80. Maddesine dayanılarak vergilerin \%7,5 geçmemek şartıyla dolaysız vergiler üzerine "küsurat-ı munzamma tarhı" yapıması için vilayet meclislerine yetki verilmişti (Akkuş, a.g.t, s. 397).
}

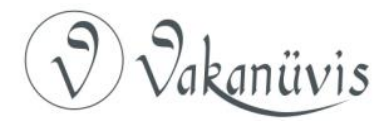


olarak kullanılmış ve örneğin İzmit-Akmeşe yolunun inşaat masrafı için mutasarrıflığın fazla geliri olan 1916 yılı bütçe fazlası tahsisat-ı fevkalade adıyla 450.000 kuruş olarak bu alana aktarılmıştı ${ }^{43}$.

Savaşın başında seferberlik dolayısıyla inşaatı sekteye uğrayan ve amele taburları vasıtasıyla inşaatına devam edilen Adapazarı-Karasu yolunun $^{44}$ akıbetinin ne olduğu meçhuldür. Benzer durum Adapazarı'nın diğer kazalarla olan yolları için de geçerlidir. Ödenek yetersizliği, İzmit-Akmeşe yolu örneğinde olduğu gibi, bütçeler içinde nakiller yapılarak giderilmeye çalışılmıştır. Nitekim Adapazarı kazasındaki köprülerin tamiri için gerekli para olmayınca ilgili faslın ilgili maddesine encümen kararıyla nakil yapılmıştır ${ }^{45}$. Bu arada hem bütçelerde hem de raporun turuk ve maabirle ilgili programında köprü yapımı konusunun geri plana itildiği görülecektir.

İzmit'in en önemli sorunlarından olan bataklık konusu fevkalade bütçeler içinde yer alan eğitimden sonraki en önemli kalemdi ve mutasarrıflık yönetimi 1916 yılında İzmit bataklıkları için 50.000 Geyve için de 30.000 kuruş olmak üzere toplamda 80.000 kuruş ayırmıştı ${ }^{46}$. 1917 yılı içinde yine aynı şekilde bu kez İzmit Körfezi'ndeki bataklığın kurutulması için para ayrıldığı ve tutarın da 100.000 kuruş olduğu görülecektir ${ }^{47}$. Savaşın son yılında konuyla ilgili herhangi bir meblağ bütçeye konulmamış ve şehrin belki de en ciddi sorunu olan bataklık konusunun üzerine daha o yıllarda gidilmediği için aynı sorun uzun yıllar İzmitlilerin gündemini işgal etmiştir.

Köprü ve yol yapımındaki ödenek miktarını büyük oranda düşüren mutasarrıflık yönetimi eğitimle ilgili giderlerde tam tersi bir uygulama içine girdi; miktarı bir hayli arttırdı. Ayrıca ödenek ilaveleri ve sıklıkla görülen fasıldan fasıla nakil de en çok eğitim için yapıldı. Bu durum mutasarrıflığın uygulamakla yükümlü olduğu kanun maddelerinden kaynaklanmaktaydı. Tedrisat-ı İbtidaiyye Kanunu uyarınca 100 ve 100 'den çok hane bulunan köylerde bir ibtidai mektep inşa edilecek ve bu mektep inşaatları için gerekli meblağ vilayet bütçelerince

\footnotetext{
${ }^{43}$ BOA, i.DUiT, 134-31, ek 1: 12 Temmuz 1332/25 Temmuz 1916.

${ }^{44}$ inal, a.g.e., s. 13.

${ }^{45}$ BOA, I.DUiT, 131-10, ek 8: 18 Ağustos 1333/1917

${ }^{46}$ BOA, I. DUiT, 134-32: 1916 yılı bütçe kitapçı̆̆ı.

${ }^{47}$ BOA, I.DUiT, 134-27: 1917 yılı bütçe kitapçığı.
}

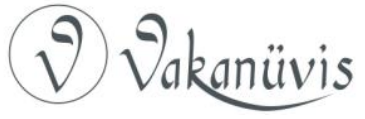


karşılanacaktı. Vilayet yönetimleri parayı köy ahalisinden toplayacak ve köyün nüfusu bu noktada önem kazanacaktı. Bu karardan hareketle mutasarrıfık yönetimi ahaliden alınacak vergi miktarını hane başına 34 kuruş olarak belirlenmişse de Dahiliye Nezareti tarafından ahval-i harbiye dolayısıyla ahaliye fazla bir bar olmaması istenmişti ${ }^{48}$. Kısacası ilköğretime ait hem maaş ödemelerinin hem de okul inşaatlarının vilayet bütçelerinden karşılanması bu faslın şişirilmesi anlamına geliyordu. TABLO IV'te de görüldüğg̈ gibi mutasarrıflığın 1916, 1917 ve 1918 yıllarına ait fevkalade bütçelerinin eğitim giderlerinin tamamı mekteb-i ibtidai yapımı için ayrılmış ve 1916 'da \%70, 1917'de \%64, 1918 'de \%52.6 gibi oldukça yüksek bir yüzde tutturulmuştu.

5 yıllık plana göreyse İzmit ve bağlı kazalarda 1917 'den itibaren $25^{\prime}$ e yakın okuldan bir kısmının yarım olan inşaatı bitirilecek, bir kısmı yeniden inşa edilecekti. Programdaki hedeflerin Tedrisat-ı İbtidaiyye Kanunu'na uydurulduğu ve bu doğrultuda, nüfus oranı elverdiği şekilde bir ibtidai mektep inşaatı için uğraşıldığı anlaşılmaktadır ${ }^{49}$.

Mutasarrıflık yönetiminin maarifle ilgili yükümlülükleri ibtidai mekteplerle bitmiyordu. 1915 yılında Adapazarı Mekteb-i İdadisi personelinin maaş ödemeleri ve okulun masrafları için toplamda 119.200 kuruş ayrılırken, aynı yıl İzmit Darülmuallimîni için bütçeye ödenek konulmuştu ${ }^{50}$. Fakat bütçeler içindeki rakamların gerçekçi olmadığı, çok kere bütçe yapılsın diye yapıldığı hissi uyanmaktadır.

\footnotetext{
${ }^{48}$ BOA, DH.UMVM, 26-7, ek 1: 1 Nisan 1331/14 Nisan 1915.

${ }^{49}$ BOA, DH.UMVM, nr. 85-28, ek 2: 23 Mayıs 1332/5 Haziran 1916

Daha savaşın başında livada ilköğretim kurumlarını denetlemek adına müfettişler tayin edildiği bilinmektedir ve bu da eğitim adına önemlidir (Ayın Kazım, "Açık Sütunlarİmit'ten Bir Nida-yı Şükran", Musavver Malumat-ı Nafia, 1. Sene, sayı: 10 (17 Nisan 1330) s. 148).

${ }^{50}$ Darülmuallimîn 14 Eylül 1915'te açılmıştır. (Nuri Güçtekin, “I. Dünya Savaşı́nın İzmit Eğitim Kurumlarına Etkisi", Uluslararası Gazi Süleyman Paşa ve Kocaeli Tarihi Sempozyumu III, s. 2183). Okulun eğitime başladığı bina Fransız Mektebi'ydi. Daha sonra darülmualimîn bu binadan taşınmıştır (Atilla Oral, Misyonerlerin ve Fransa'nın baskısıyla görevinden azledilen Izmit Mutasarrıfı Selim Sırrı Paşa, İstanbul, 2010, s. 221).

İzmit Mutasarrıflığı darülmuallimîn için 1916 yılında 241.800, 1917 yılında 273.800 1918 yılındaysa 610.150 kuruş ödenek ayırmıştı (BOA, İ. DUiT, 134-32: 1916 yılı bütçe kitapçı̆̆ı; i.DUiT, 134-27: 1917 yılı bütçe kitapçığı; I.DUiT, 131-10: 1918 yılı bütçe kitapçı̆̆ı).
}

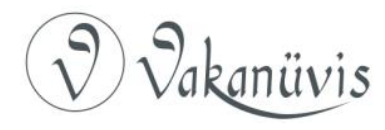


Sayıca birden fazla ilkokul açılacağı hem bütçede hem de ilgili raporda anılmakla birlikte, 1918 yılında İmit merkez kazada resmi ibtidai okullardan sadece Akçakoca Zükur íbtidaisi açıktı. 5 özel ibtidai mektebin bulunduğu İzmit merkezde, 3 Eylül 1917 tarihli bir sayımda, 310'u erkek 258'i kız toplam 568 çocuk sayılmıştı. Aynı şekilde izmit Mekteb-i Sultanisi de savaştan çok farklı bir şekilde nasibini almıştı; 1915 yılında 30 öğrencisinden 29'u Çanakkale ve diğer cephelerde askerlik vazifesini yapmak için çağrılmışlardı ${ }^{51}$. Okulların kapalı olduğu, dolayısıyla eğitimin durduğu savaş ortamında, öğretmen maaşlarının ülke genelinde ödenemediğinin bilinen bir gerçek olduğu sırada, mutasarrıflık bütçeleri içindeki eğitimle ilgili giderleri açıklamak gerçekten güçtür.

Mutasarrıflık yönetimi, 5 yıllık planlar içinde yer alan ziraat, baytarlık ve sanayi konusundaki hedeflerini de hesaba katarak bütçedeki tahmini giderleri belirlemişti. Adî ve fevkalade bütçeler içindeki ilgili kısım ve fasıllardaki ödeneklerin neredeyse tamamına yakını ziraat ve hayvanat depolarının müstahdem maaşları için ayrılırken, raporlardaysa konunun öznesine öncelik verilmişti. Bu da hayvancılıkta damızlık depoların inşaası ve damızlık hayvan alımı, ziraatteyse tohum ıslahı ve İzmit'te bir numune tarlası kurmaktı. Bir diğer dikkat çeken konu yarışma ve müsabakaya verilen önem olarak kendisini göstermekte ve at yarışları ve ziraat ürünleriyle ilgili yarışma ve o dönem sıklıkla yapılan sergilere öncelik tanınmaktaydı. Bu başlıklar doğrultusunda raporların 1917 ve 1918 yılı için hedeflediği rakam 1917 yılı için 250.000 kuruşken $^{52}, 1918$ yılında büyük bir düşüşle 145.000 kuruş olarak gösterilmiştir ${ }^{53}$. Bu düşüşün etkisiyle olsa gerek 1918 yılı adî ve fevkalade bütçelerindeki aynı fasla ayrılan gider miktarı cüz'i de olsa yükselmiştir ${ }^{54}$. 1918 yılı adî bütçesi içinde ilk defa açılan sanayi faslıysa sanılanın aksine İzmit'teki sanayi kuruşları için değil

\footnotetext{
${ }^{51}$ Güçtekin, a.g.m, s. 2175, 2177, 2180.

52 BOA, DH.UMVM, 85-28, ek 2: 23 Mayıs 1332/5 Haziran 1916: 1917 yılı bütçesinde "umur-ı ziraiyye ve baytariyye" kısmındaysa 67.100 kuruş gösterilmişti (BOA, I.DUiT, 134-27: 1917 yılı bütçe kitapçığı)

${ }^{53}$ BOA, DH.UMVM, 85-28, ek 2: 23 Mayıs 1332/5 Haziran 1916.

${ }^{54}$ BOA, I. DUIT, 131-10: 1918 yılı bütçe kitapçı̆̆ı.
}

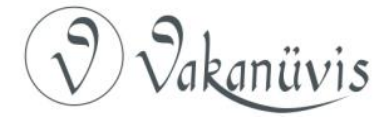


demircilik sanatı öğrenmek için fabrikaya gönderilecek üç öğrenci için $\operatorname{vardi}^{55}$.

Tohum ıslahı ve numune tarla kurmak Ziraat Nezareti'nin görev alanlarından olmakla birlikte savaş şartları içinde pek çok yerleşim birimine gerekli tohum ulaştırılamamıştı. İmit'te tohumluk dağıtımı sorunu daha savaşın başında yapılan teftişlere konu olmuş ve gerekli tohumun geliş tarihinin gecikmesi nedeniyle ekim yapılamamış ve nadasa bırakılmıştı. İzmit Mutasarrıfı Mazhar Bey'in ifadesiyle Ziraat Nezareti'yle muhabere neticeye ulaşamamış ve 50.000-60.000 dönüm arazi savaş ortamında boş kalmıştı ${ }^{56}$.

Bütçeler içinde Umur-ı Hayriye ve Sıhhiye başlığı altında ayrılan gider tutarı bütçe içindeki en küçük orana denk gelmekte ve hastane personelinin maaş ödemeleri ve hastanelere ait genel ödemeler için para ayrılmaktadır. Özellikle İzmit'teki hastane için ayrılan ödenekler yeterli gelmemiş, yıl yıl yapılan ilave aktarımlarla sağlık kurumunun ihtiyaçları sağlanmaya çalışımıştı ${ }^{57}$. Raporlarda ise bu kısım adeta boş bırakılmıştı.

\section{Sonuç}

Birinci Dünya Savaşı yıllarında ilgili kanun ve tarifname doğrultusunda hazırlanan İzmit Mutasarrıflığı bütçeleri için ilk söylenecek, gelir gider dengesini tutturma, var olanı sürdürme ve bir görevi yerine getirme anlayışının ön planda olduğu gerçeğidir. Bu gerçek, gider fasıllarını merkeze alarak, şu iki örnekle güçlendirilebilir: Birincisi değerlendirilen üç yılın bütçelerinde eğitim giderlerinin payı yüksek olmasına rağmen mutasarrıflığın merkezi olan İzmit'te tek bir devlet ilkokulunda eğitim verilmesidir. Şehirde orta eğitim seviyesinde okullarla, yeni açılan darülmuallimîn mevcut olsa da, bu eğitim kurumlarında sağlıklı bir plan ve programın yürütüldüğünü iddia etmek

\footnotetext{
${ }^{55}$ BOA, I. DUIT, 131-10: 1918 yılı bütçe kitapçı̆̆ı.

${ }^{56}$ BOA, DH.iUM, E101-18, ek 1: 11 Kanun-i evvel 1331/24 Aralık 1915.

571918 senesi bütçesinin gider kısmında yer alan fasıllardan yapılan kesintilerle hastane için 50.000 kuruşun ayrıldığı anlaşılmaktadır (BOA, I.DUiT, 131-10, ek 1: 11 Kanun-i sani 1335/1919) Nakil yapılan kısım alat-ı ziraiyye depoları faslıdır (BOA, i.DUiT, 131-10: 1918 yılı bütçe kitapçığı).
}

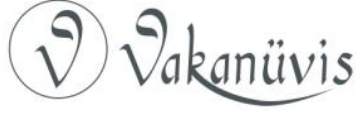


güçtür. İkincisi bütçelerin, köprü ve yol yapımı başta olmak üzere bayındırlık alanı olarak değerlendirilen gider kalemlerinde görülen rakamlarla beş yıllık raporda geçen yol güzergâhlarının inşasının mümkün olmayacağı gerçeğidir.

Verilen iki örnek bütçelerin resmi formaliteleri yerine getirmek adına hazırlandığı, sadece kitapçık üzerinde kaldığı iddiasını güçlendirmekle birlikte, tahmini gelir ve giderlerden oluşan bütçelerin gerçekleşme verilerinin günümüze ulaşmaması bu iddianın üzerine perdelemektedir. Bayındırlık faaliyetleri olarak değerlendirilen yol ve köprü yapımı giderleriyle ilgili veriler, Birinci Dünya Savaşı yıllarından İmit Mutasarrıflığı sınırları içinde kaç km yol yapıldığı, mevcut yolların bakımının yapılıp yapılmadığı yönünde net bilgilere sahip olmadığımız için büyük bir anlam ifade etmemektedir.

En kayda değer sonuçsa bütçeler içindeki gelir kalemlerinde görülmektedir ki o da köylüden alınan verginin gelir faslının temelini oluşturduğudur. Gider kalemlerindeyse memurların maaş ödemelerine yoğunluk verilmiş köylü içinse ancak ilkokul yapmak gibi gerçekleşip gerçekleşmediği belli olmayan faaliyet içine girilmiştir. Fakat merkezin özellikle eğitimle ilgili vergi toplama işlemi sırasında savaşın yarattığı etkiyi göz önünde tutarak halkın üzerine fazla gidilmemesi konusunda mutasarrıflık yönetimini uyardığı da bir gerçektir.

\section{Kaynakça}

\section{Arşiv Belgeleri}

Başbakanlık Osmanlı Arşivi (BOA), DH.iUM, 26-10

BOA, DH.iUM, E101-18

BOA, DH.UMVM, 8-11

BOA, DH.UMVM, 26-7

BOA, DH.UMVM, 26-10

BOA, DH.UMVM, 37-15

BOA, DH.UMVM, 45-3

BOA, DH.UMVM, 85-28

BOA, I.DUIT, $128-80$

BOA, I.DUIT, 128-81

BOA, I. DUIT, 131-10

BOA, I. DUIT, 131-11

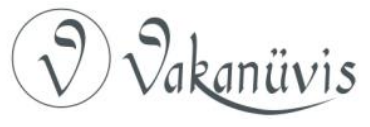




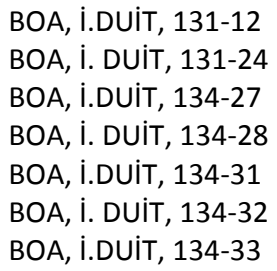

Akkuş, Yakup. Osmanlı Taşra Maliyesinde Reform: Merkez-Taşra Arasındaki idarî-Malî Ilişkiler ve Vilayet Bütçeleri (1864-1913), İstanbul Üniversitesi Sosyal Bilimler Enstitüsü Yayınlanmamış Doktora Tezi, İstanbul 2011.

Ayın Kazım, "Açık Sütunlar-İzmit'ten Bir Nida-yı Şükran”, Musavver Malumat-ı Nafia, 1. Sene, sayı: 10 (17 Nisan 1330) s. 148-149.

Bilâ-Vasıta Tekâliften Bazılarına Vilayât Hissesi Olarak İcra Edilen Zamaim ile Zebhiye Rüsûmunun Miktarı Ve Tarik-i Mükellefiyet Nakdiyesi Hakkındaki Kavanin-i Muvakkate ile Zebhiye Resmi Hakkındaki Kanuna Tezyil Olunan Mevad-ı Muvakkata-i Kanuniyye Suretleridir, Hilal Matbaası, Dersaadet, Tarih belirtilmemiş.

Bostan, İdris. "İzmit", DiA, c. 23, Türkiye Diyanet Vakfı, İstanbul, 2001, ss. 536-541.

Güçtekin, Nuri. “I. Dünya Savaşı'nın İzmit Eğitim Kurumlarına Etkisi”, Uluslararası Gazi Süleyman Paşa ve Kocaeli Tarihi Sempozyumu III, Kocaeli Büyükşehir Belediyesi Kültür ve Sosyal İşler Dairesi Başkanlığı Yayınları, Kocaeli, 2017, ss. 2171-2192.

Inal, Nail. İzmit Sancağı 1330 Büdcesi ve Meclis-i Umûm (1 Mart 1914-1 Mart 1915), Kocaeli Dökümantasyon Merkezi Yayınları, İzmit, 2010.

Muhasebe-i Hususiyyelerde Tutulacak Kuyûd ve Defâtir-i Hesabiyye Hakkındaki Talimatnâmenin Vilayet Bütçelerinin Suret-i Tertib ve Tanzimine Dair Olan Mevâddını Muaddil Talimatnâmedir, Hilal Matbaası, Dersaadet, 1330.

Oral, Atilla. Misyonerlerin ve Fransa'nın baskısıyla görevinden azledilen İzmit Mutasarrıfı Selim Sırrı Paşa, Demkar Yayınevi, İstanbul, 2010.

Osmanlı Belgelerinde Kocaeli, Kocaeli Büyükşehir Belediyesi Kültür ve Sosyal İşler Dairesi Başkanlığı Yayınları, İstanbul, 2017.

Özel, Sabahattin. Milli Mücadelede Izmit-Adapazarı ve Atatürk, 2. baskı, Derin Yayınları, İstanbul, 2009.

Sofuoğlu, Adnan. Kuva-yı Milliye Döneminde Kuzeybatı Anadolu 19191921, Genelkurmay Basım Evi, Ankara, 1994.

Şahin, Enis-Sinan Demirağ, "Kocaeli Vilayeti'nin Teşekkül Süreci”, Uluslararası Gazi Süleyman Paşa ve Kocaeli Tarihi Sempozyumu III, c. II, Kocaeli Büyükşehir Belediyesi Kültür ve Sosyal İşler Dairesi Başkanlığı Yayınları, Kocaeli, 2017, ss. 1461-1505.

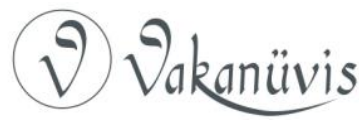


Tuna, Serkan. "Kal'a-yı Sultaniye Vilayet Bütçeleri (1915-1922)", Çanakkale Tarihi, c. VI, ed. Mustafa Demir, Değişim Yayınları, İstanbul, 2008, ss. 31673193.

Vilayât Muhasebe-i Hususiyyelerinde Tutulacak Kuyûd ve Defâtir-i Hesabiyye Hakkında Tarifname, Matbaa-yı Osmaniye, Dersaadet, 1329. 